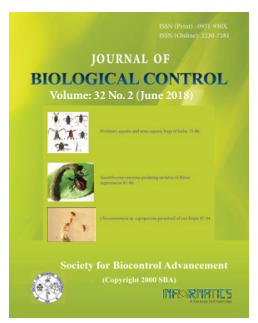

\title{
On-farm impact of egg parasitoid, Trichogramma spp. against lepidopteran pests in organic basmati rice
}

\author{
K. S. SANGHA, P. S. SHERA*, SUDHENDU SHARMA and RABINDER KAUR \\ Biocontrol Section, Department of Entomology, Punjab Agricultural University, Ludhiana - 141004, Punjab, India \\ *Corresponding author E-mail: psshera@pau.edu
}

\begin{abstract}
On farm impact of Trichogrammatids was studied against lepidopteran pests, i.e., yellow stem borer, Scirpophaga incertulas (Walker) and leaf folder, Cnaphalocrocis medinalis (Guenee) in organic basmati rice (var. Pusa 1121) over an area of 20 and 60 hectares during 2014 and 2015, respectively. Six augmentative releases of Trichogramma chilonis and T. japonicum each@1,00,000 parasitoids/ha were made starting from 30 days after transplanting (DAT) and was compared with untreated control. Based on the overall mean, the biocontrol treatment $(1.74 \% \mathrm{DH})$ was significantly effective in reducing the dead heart incidence as compared to untreated control $(4.52 \% \mathrm{DH})$. The reduction in dead hearts was 61.50 per cent in biocontrol over untreated control. The mean incidence of white ears was also significantly lower in biocontrol field (2.05\%) as against untreated control (4.89\%) resulting in a reduction of 58.08 per cent. Similarly, leaf folder damage in biocontrol (2.04\% LFDL) resulted in 62.50 per cent reduction over untreated control (5.44\% LFDL). Grain yield in biocontrol fields $(29.81 \mathrm{q} / \mathrm{ha})$ was 18.76 per cent more than the untreated control $(25.10 \mathrm{q} / \mathrm{ha})$. The increase in yield due to control of stem borers and leaf folder in biocontrol fields resulted in an additional benefit of INR 16332/- and INR 9818/- during 2014 and 2015, respectively. Conclusively, 6 releases of T. chilonis and T. japonicum each @ 1,00,000/ha resulted in lower incidence of rice insect pests and higher grain yield in organic basmati rice with an additional benefit over untreated control.
\end{abstract}

KEY WORDS: Biocontrol, Cnaphalocrocis medinalis, Scircophaga incertulas, Trichogramma augmentation

(Article chronicle: Received: 06-03-2018; Revised: 10-06-2018; Accepted: 15-06-2018)

\section{INTRODUCTION}

Rice is the most important cereal food crop of India, ranking second in the world's rice producers, with production of 106.50 million metric tons (USDA-FAS, 2016). Basmati rice occupies a special status in rice cultivation for its excellent cooking attributes. India produces more than 70 per cent of the total world basmati rice with Punjab, Haryana, Uttar Pradesh and Jammu and Kashmir as major growing states (Singh, 2011). In Punjab state, area under basmati rice was 8.63 and 7.63 lakh hectares during 2014-15 and 2015-16, respectively predominantly occupied by variety Pusa Basmati 1121 (83.65\%). Rice is essentially crop of warm and humid environment conducive to survival and proliferation of many insect pests. More than 100 species of insects have been reported to ravage the rice crop, of these 15-20 are considered to be economically important (Kalode, 2005). The overall losses due to insect damage in rice have been estimated to be 25 per cent (Dhaliwal et al., 2010). Among these, rice stem borers viz. yellow stem borer, Scirpophaga incertulas
(Walker); white stem borer, S. innotata (Walker) and pink stem borer, Sesamia inferens (Walker) and leaf folder, Cnaphalocrocis medinalis (Guenee) are of utmost importance in Punjab causing huge reductions in yield (Singh et al., 2002). The larval feeding of all three borer species results in 'dead hearts' during vegetative stage and sterile panicles or 'white ears' during reproductive stage. Leaf folder larvae fasten the edges of leaves together, fold them longitudinally and feed on green matter from inside the fold, leaving behind the whitish membranes. In the absence of genetic resistance against these pests, farmers have relied heavily on insecticides for their effective management. However, indiscriminate use of insecticides has led to many ecological backlashes like environmental pollution, resistance to pesticides and pest resurgence besides lethal effect to non target organisms and health hazards to users. The awareness for the consumption of ecologically safe food has provided impetus to organic farming in India and intensive efforts have been made to find out alternate methods of pest control (Nathan et al., 2004). 
Among management practices, biological control through use of natural enemies provides an environmental friendly and effective method of minimizing the pest damage. Egg parasitoids in the genus Trichogramma (Hymenoptera: Trichogrammatidae) have been widely used for biological control of Lepidopteran insect pests (Garg et al., 2002; Bueno et al., 2010; Shawer et al., 2013; Ko et al., 2014). In Punjab, augmentative releases of Trichogramma chilonis Ishii and T. japonicum Ashmead@1,00,000 each have been found effective for the biological suppression of yellow stem borer, S. incertulas and leaf folder, C. medinalis in organic rice (Brar et al., 1999; Kaur and Brar, 2008). The present study was, therefore conducted to validate and promote this technology in organic farming for large scale adoption at farmers' fields in the Punjab state.

\section{MATERIALS AND METHODS}

Large scale demonstrations for the management of rice stemborers and leaffolder using egg parasitoids were conducted at farmers' fields in organic basmati rice (var. Pusa 1121) over an area of 20 and 60 hectares during 2014 and 2015, respectively. Six augmentative releases of T. chilonis and T.japonicum each @1,00,000 parasitoids/ ha were made starting from 30 Days After Transplanting (DAT) and was compared with untreated control. The culture of T. chilonis was maintained in the Biological Control Laboratory, Department of Entomology, Punjab Agricultural University (PAU), Ludhiana. Tricho-cards each having approximately 1000 parasitized eggs were cut into 100 strips and were stapled uniformly to the underside of the leaves in biocontrol treatment. The observations on stem borers infestation (dead hearts), leaf folder damage leaves (at least $1 / 3^{\text {rd }}$ leaf area damaged) were recorded from randomly selected 20 hills at vegetative stage, i.e., 45 and 60 DAT. White ears incidence by stem borers was recorded one week prior to harvest of the crop. Grain yield was recorded on plot basis and economics was worked out. The data pertaining to per cent Dead Hearts (DH), per cent White Ear (WE) due to stemborer and per cent damaged leaves (LFDL) due to leaf folder were subjected to arc sine transformations prior to statistical analysis. The data of different parameters were analyzed using ANOVA. The different treatment means were separated by Least Significant Difference test (LSD) at $p=0.05$ (Gomez and Gomez, 1984).

\section{RESULTS AND DISCUSSION}

\section{Stem borers infestation}

The mean incidence of stem borers in terms of dead hearts during vegetative stage and white ears during reproductive stage of the rice crop was significantly lower in biocontrol fields as compared to untreated control during the years, 2014 and 2015.

Dead hearts: In the year 2014 (Table 1), the dead heart incidence at 45 DAT was 1.45 and 4.48 per cent in biocontrol field and untreated control, respectively. The corresponding figures at 60 DAT were 1.92 and 5.72 per cent. The mean dead hearts during 2015 in biocontrol fields was 1.54 and 2.00 per cent as against 3.63 and 4.96 per cent in untreated control at 45 and 60 DAT, respectively (Table 1). Based on the overall mean, the biocontrol treatment $(1.74 \%)$ involving augmentative releases of $T$. chilonis and $T$. japonicum was significantly effective in reducing the dead heart incidence as compared to untreated control $(4.52 \%)$. The reduction in dead hearts (pooled over two years) was 61.50 per cent in biocontrol over untreated control (Fig. 1).

Table 1. Effect of biocontrol practices on dead heart incidence due to stem borers in organic basmati rice

\begin{tabular}{|c|c|c|c|c|c|c|c|}
\hline \multirow{3}{*}{ Treatments } & \multicolumn{7}{|c|}{ Dead hearts $(\%)$} \\
\hline & \multicolumn{3}{|c|}{45 DAT } & \multicolumn{3}{|c|}{60 DAT } & \multirow{2}{*}{$\begin{array}{c}\text { Over all } \\
\text { Mean }\end{array}$} \\
\hline & 2014 & 2015 & Mean & 2014 & 2015 & Mean & \\
\hline Biocontrol $^{*}$ & $1.45^{\mathrm{a}}$ & $1.54^{\mathrm{a}}$ & $1.51^{\mathrm{a}}$ & $1.92^{\mathrm{a}}$ & $2.00^{\mathrm{a}}$ & $1.98^{\mathrm{a}}$ & $1.74^{\mathrm{a}}$ \\
\hline $\begin{array}{l}\text { Untreated } \\
\text { control }\end{array}$ & $4.48^{\mathrm{b}}$ & $3.63^{\mathrm{b}}$ & $3.87^{\mathrm{b}}$ & $5.72^{\mathrm{b}}$ & $4.96^{\mathrm{b}}$ & $5.18^{\mathrm{b}}$ & $4.52^{\mathrm{b}}$ \\
\hline t value & 6.20 & 8.22 & 9.71 & 8.07 & 11.74 & 13.62 & 13.06 \\
\hline$p$ value & 0.0008 & $<0.0001$ & $<0.0001$ & 0.0002 & $<0.0001$ & $<0.0001$ & $<0.0001$ \\
\hline
\end{tabular}

DAT - days after transplanting; *6 releases of Trichogramma chilonis and T. japonicum each @ 1,00,000/ha at weekly interval starting from 30 DAT 


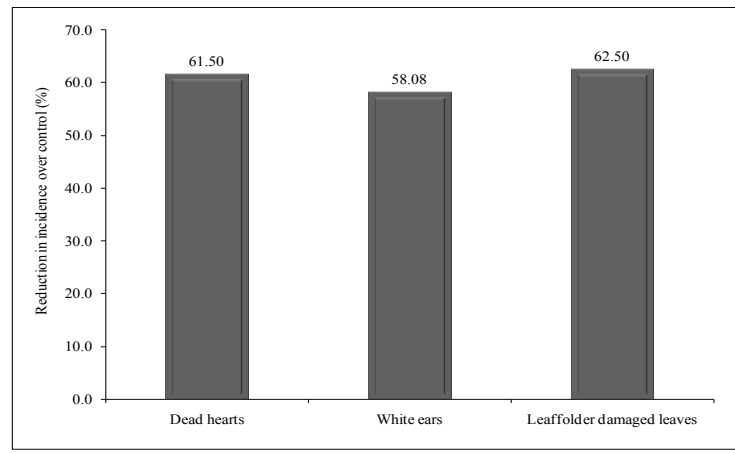

Fig. 1. Effect of biocontrol practices on per cent reduction in incidence over control in organic basmati rice (pooled mean of two years).

White ears: During 2014 (Table 2), the white ear incidence in biocontrol fields $(2.02 \%)$ was significantly effective in reducing the stem borer damage as compared to untreated control $(6.60 \%)$. Similar trend was observed in 2015 also. The mean white ears in biocontrol and untreated control were 2.07 and 4.16 per cent, respectively. Based on the overall mean, the biocontrol treatment $(2.05 \% \mathrm{WE})$ resulted in 58.08 per cent reduction (Fig. 1) in white ear incidence over untreated control $(4.89 \% \mathrm{WE})$.

The present results on rice stem borer corroborate with the findings of Kaur and Brar who reported that the seven releases of T. chilonis and T. japonicum @ 1,00,000 per ha effectively controlled yellow stem borer in basmati rice. The study also finds support from the findings of Kumar and Khan who reported that innundative releases of T. chilonis and T.japonicum @100000/ha reduced the tiller damage by 78.1 to 81.6 per cent over control.

\section{Leaf folder infestation}

The mean leaf folder damage observed during vegetative stage at 45 and 60 DAT was significantly lower in biocontrol fields as against untreated control during both the years, 2014 and 2015. The damaged leaves during 2014 in biocontrol fields were 1.20 and 1.78 per cent as against 5.09 and 6.45 per cent in untreated control at 45 and 60 DAT, respectively (Table 3). During 2015, the leaf folder damaged leaves at 45 DAT was 2.04 and 4.61 per cent in biocontrol field and untreated control, respectively. The corresponding figures at 60 DAT were 2.47 and 6.01 per cent (Table 3). Based on the overall mean, the biocontrol treatment $(2.04 \%$ LFDL) resulted in 62.50 per cent reduction of leaf folder damage over untreated control (5.44\% LFDL). The present study is in consonance with Sagheer et al., who confirmed the efficacy of egg releases of Trichogramma sp. @ 100000 and 1250000 per hectare in reducing per cent infestation of the leaf folder. Similarly, Kumar and Khan reported that parasitoid releases at 100000 /ha significantly reduced leaf folder damage up to 72.6 to 81.8 per cent.

Table 2. Effect of biocontrol practices on white ears due to stem borers and yield in organic basmati rice

\begin{tabular}{|l|c|c|c|c|c|c|c|}
\hline \multirow{2}{*}{ Treatments } & \multicolumn{3}{|c|}{ White ears (\%) } & \multicolumn{4}{c|}{ Paddy yield (q/ha) } \\
\cline { 2 - 8 } & 2014 & 2015 & Mean & 2014 & 2015 & Mean & \% increase over control \\
\hline Biocontrol $^{*}$ & $2.02^{\mathrm{a}}$ & $2.07^{\mathrm{a}}$ & $2.05^{\mathrm{a}}$ & $32.00^{\mathrm{a}}$ & $28.93^{\mathrm{a}}$ & $29.81^{\mathrm{a}}$ & 18.76 \\
\hline Untreated control $^{*}$ & $6.60^{\mathrm{b}}$ & $4.16^{\mathrm{b}}$ & $4.89^{\mathrm{b}}$ & $26.88^{\mathrm{b}}$ & $24.39^{\mathrm{b}}$ & $25.10^{\mathrm{b}}$ & - \\
\hline t value & 4.40 & 5.36 & 6.90 & 4.17 & 6.52 & 6.16 & \\
\hline p value & 0.0046 & $<0.0001$ & $<0.0001$ & 0.0059 & $<0.0001$ & $<0.0001$ & \\
\hline
\end{tabular}

DAT - days after transplanting; "6 releases of Trichogramma chilonis and T. japonicum each @ 1,00,000/ha at weekly interval starting from 30 DAT

Table 3. Effect of biocontrol practices on leaf folder damaged leaves in organic basmati rice

\begin{tabular}{|c|c|c|c|c|c|c|c|}
\hline \multirow{3}{*}{ Treatments } & \multicolumn{7}{|c|}{ Leaf folder damaged leaves $(\%)$} \\
\hline & \multicolumn{3}{|c|}{45 DAT } & \multicolumn{3}{|c|}{$60 \mathrm{DAT}$} & \multirow{2}{*}{$\begin{array}{c}\text { Over all } \\
\text { Mean }\end{array}$} \\
\hline & 2014 & 2015 & Mean & 2014 & 2015 & Mean & \\
\hline Biocontrol* & $1.20^{\mathrm{a}}$ & $2.04^{\mathrm{a}}$ & $1.80^{\mathrm{a}}$ & $1.78^{\mathrm{a}}$ & $2.47^{\mathrm{a}}$ & $2.27^{\mathrm{a}}$ & $2.04^{\mathrm{a}}$ \\
\hline Untreated control & $5.09^{\mathrm{b}}$ & $4.61^{\mathrm{b}}$ & $4.75^{b}$ & $6.45^{\mathrm{b}}$ & $6.01^{\mathrm{b}}$ & $6.14^{\mathrm{b}}$ & $5.44^{\mathrm{b}}$ \\
\hline t value & 21.40 & 12.26 & 15.00 & 15.72 & 22.00 & 22.63 & 17.89 \\
\hline $\mathrm{p}$ value & $<0.0001$ & $<0.0001$ & $<0.0001$ & $<0.0001$ & $<0.0001$ & $<0.0001$ & $<0.0001$ \\
\hline
\end{tabular}

DAT - days after transplanting; "6 releases of Trichogramma chilonis and T. japonicum each @ 1,00,000/ha at weekly interval starting from 30 DAT 
Table 4. Effect of Trichogramma chilonis releases for the management of lepidopteran pests on economic returns in organic basmati rice

\begin{tabular}{|c|c|c|c|c|c|}
\hline Treatments & $\begin{array}{l}\text { Yield } \\
(\mathrm{q} / \mathrm{ha})\end{array}$ & $\begin{array}{l}\text { Additional yield over } \\
\text { control }(\mathrm{q} / \mathrm{ha})\end{array}$ & $\begin{array}{l}\text { Gross returns } \\
\text { (Rs) }\end{array}$ & $\begin{array}{l}\text { Cost of treat- } \\
\text { ment* (Rs/ha) }\end{array}$ & $\begin{array}{l}\text { Net return over } \\
\text { control (Rs/ha) }\end{array}$ \\
\hline \multicolumn{6}{|l|}{2014} \\
\hline Biocontrol $^{*}$ & $32.00^{\mathrm{a}}$ & 5.12 & 18432.00 & 2100 & 16332.00 \\
\hline Untreated control & $26.88^{\mathrm{b}}$ & - & - & - & - \\
\hline \multicolumn{6}{|l|}{2015} \\
\hline Biocontrol $^{*}$ & $28.93^{\mathrm{a}}$ & 4.54 & 11917.50 & 2100 & 9817.50 \\
\hline Untreated control & $24.39^{b}$ & - & - & - & - \\
\hline
\end{tabular}

Market price of organic basmati rice @ Rs 3600/- and 2625/- per quintal in 2014 and 2015, respectively; include cost of tricho-cards

\section{Paddy yield and economic returns}

During 2014 (Table 2), paddy yield in biocontrol fields $(32.00 \mathrm{q} / \mathrm{ha})$ was significantly better as compared to untreated control $(26.88 \mathrm{q} / \mathrm{ha})$. The paddy yield in biocontrol and untreated control were $28.93 \mathrm{q} /$ ha and $24.39 \mathrm{q} / \mathrm{ha}$, respectively during 2015. Based on the mean of two years, yield increase in the biocontrol treatment (29.81 q/ha) was 18.76 per cent more than untreated control $(25.10 \mathrm{q} / \mathrm{ha})$. The increase in yield due to control of stem borers and leaf folder infesting rice crop in biocontrol fields resulted in net profit of INR 16332/- over untreated control during 2014. During 2015 also, an additional benefit of INR 9818/- was obtained in biocontrol fields with augmentative releases of Trichogramma chilonis and T. japonicum as compared untreated control (Table 4). Karthikeyan et al. also reported similar results wherein, releases of $T$. japonicum and $T$. chilonis (a) 1,00,000 per ha resulted in increased paddy yields by 25.79-45.13 per cent over insecticide treated plots, with a $\mathrm{C}: \mathrm{B}$ ratio of $1: 2.6$ and $1: 1.9$ in parasitoid released and insecticide treated plots, respectively.

Conclusively, biocontrol package involving six releases of Trichogramma chilonis and T. japonicum each @ $1,00,000 /$ ha resulted in lower incidence of stem borers and leaf folder and higher grain yield with an additional benefit in terms of monetary returns in organic basmati rice. It could be a viable option for the ecofriendly management of key rice pests under organic farming.

\section{REFERENCES}

Brar KS, Singh J, Shenhmar M, Bakhetia DRC, Singh J. 1999. Insect and Environment. pp. 206-210. In: Pajni H R, Tewari PK, Kaur D (Eds.). Evaluation of Trichogramma chilonis Ishii and T. japanicum Ashmead for the control of leaffolder and stem borer of rice in Punjab. Society of Environment Scientists, Chandigarh.
Bueno R, Bueno AD, Parra JRP, Vieira SS, de Oliveira LJ. 2010. Biological characteristics and parasitism capacity of Trichogramma pretiosum Riley (Hymenoptera, Trichogrammatidae) on eggs of Spodoptera frugiperda (J. E. Smith) (Lepidoptera, Noctuidae). Revista Brasileira de Entomologia 54: 322-327. https://doi. org/10.1590/S0085-56262010000200016

Dhaliwal GS, Jindal V and Dhawan AK. 2010. Insect pest Problems and crop losses: changing trends. Indian $J$ Ecol. 37: 1-7.

Garg DK, Kumar P, Singh RN, Pathak M. 2002. Role of parasitoid Trichogramma japonicum and other natural enemies in the management of yellow stemborer and leaffolder in basmati rice. Indian J Ent. 64: 117-123.

Gomez KA, Gomez AA. 1984. Statistical procedures for agricultural research, 2nd ed. John Wiley and Sons Inc, New York, USA, 704 p.

Kalode MB. 2005. Insect pests of rice and their management. In: Sharma SD and Nayak BC (Eds.). Rice in Indian Perspective. Today and Tomorrow Printers and Publishers, India. pp. 819-854.

Karthikeyan K, Jacob S, Purushothaman SM. 2007. Field evaluation of egg parasitoids, Trichogramma japonicum Ashmead and Trichogramma chilonis Ishii, against rice yellow stemborer and leaffolder. $J$ Biol Control 21: 145-148.

Kaur R, Brar KS. 2008. Evaluation of different doses of Trichogramma species for the management of leaf folder and stem borer on Basmati rice. J Biol Control 22(1): 131-135.

Ko K, Liu Y, Hou M, Babendreier, Zhang F, Song K. 2014. Evaluation for potential Trichogramma (Hymenoptera: Trichogrammatidae) strains for control of the striped 
stem borer (Lepidoptera: Crambidae) in the Greater Mekong Subregion. J Econ Entomol. 107(3): 955-963. https://doi.org/10.1603/EC13481

Kumar S, Khan MA. 2005. Bio-efficacy of Trichogramma spp. against yellow stemborer and leaffolder in rice ecosystem. Ann Pl Prot Sci. 13: 97-99.

Nathan SS, Chung PG, Murugan K. 2004. Effect of botanicals and bacterial toxin on the gut enzyme of Cnaphalocrocis medinalis. Phytoparasitica 32: 433443. https://doi.org/10.1007/BF02980437

Sagheer M, Ashfaq M, Mansoor-ul-Hasan, Rana SA. 2008. Integration of some biopesticides and Trichogramma chilonis for the sustainable management of rice leaffolder, Cnaphalocrocis medinalis (Guenee) (Lepidoptera: Pyralidae). Pak J Agri Sci. 45: 69-74.
Shawer MB, EL-Agamy FM, Hendawy AS, Refaei EA. 2013. Effect of Trichogramma evanescens West release in rice stem borer control. J Plant Prot Path Mansoura Univ. 4(3): 261-264.

Singh J, Dhaliwal GS, Singh J, Shera PS. 2002. Changing scenario of rice insect pests in Punjab and their management strategies. Indian J Ecol. 29: 208-220.

Singh J. 2011. Impact assessment study of IPM basmati project for boosting diversification process in Punjab. Navajbai Rata Tata Trust, Mumbai, India, $43 \mathrm{p}$.

USDA-FAS. 2016. World Agricultural Production. Available at: http://usda.mannlib.cornell.edu/usda/ current/worldag-production/worldag-production-12-09-2016.pdf. 